\title{
Substrate oxidation in primary human skeletal muscle cells is influenced by donor age
}

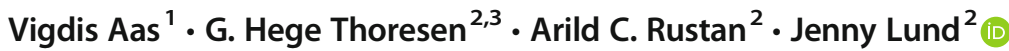

Received: 2 December 2019 / Accepted: 7 August 2020 / Published online: 8 September 2020

(C) The Author(s) 2020

\begin{abstract}
Primary human myotubes represent an alternative system to intact skeletal muscle for the study of human diseases related to changes in muscle energy metabolism. This work aimed to study if fatty acid and glucose metabolism in human myotubes in vitro were related to muscle of origin, donor gender, age, or body mass index (BMI). Myotubes from a total of 82 donors were established from three different skeletal muscles, i.e., musculus vastus lateralis, musculus obliquus internus abdominis, and musculi interspinales, and cellular energy metabolism was evaluated. Multiple linear regression analyses showed that donor age had a significant effect on glucose and oleic acid oxidation after correcting for gender, BMI, and muscle of origin. Donor BMI was the only significant contributor to cellular oleic acid uptake, whereas cellular glucose uptake did not rely on any of the variables examined. Despite the effect of age on substrate oxidation, cellular mRNA expression of pyruvate dehydrogenase kinase 4 (PDK4) and peroxisome proliferator-activated receptor gamma coactivator 1 alpha (PPARGC1A) did not correlate with donor age. In conclusion, donor age significantly impacts substrate oxidation in cultured human myotubes, whereas donor BMI affects cellular oleic acid uptake.
\end{abstract}

Keywords Skeletal muscle cells $\cdot$ Energy metabolism $\cdot$ Age $\cdot$ Body mass index (BMI) $\cdot$ Muscle of origin $\cdot$ Gender

\section{Introduction}

Primary human skeletal muscle cells (myotubes) derived from satellite cells represent an alternative system to intact skeletal muscle that can be used for the study of human diseases related to changes in energy metabolism (Aas et al. 2013; Henry et al. 1995). It has been observed that myotubes display morphological, metabolic, and biochemical similarities to adult skeletal muscle (Gaster et al. 2001; Henry et al. 1995; Thompson et al. 1996). This cell model has the most relevant genetic background, and because these cells are not immortalized, they allow investigation of the innate characteristics of

Jenny Lund

jenny.lund@farmasi.uio.no

1 Department of Life Sciences and Health, Faculty of Health Sciences, OsloMet - Oslo Metropolitan University, Oslo, Norway

2 Section for Pharmacology and Pharmaceutical Biosciences, Department of Pharmacy, University of Oslo, Blindern, P.O. Box 1068, 0316 Oslo, Norway

3 Department of Pharmacology, Institute of Clinical Medicine, University of Oslo, Oslo, Norway the donors from whom the cells were obtained (Aas et al. 2013). In addition, the extracellular environment can be precisely controlled and modulated ex vivo making myotubes a valuable system for research.

Cultured human myotubes retain some of the phenotypic traits of their donors. For instance, the diabetic phenotype is conserved in myotubes established from subjects with obesity/ type 2 diabetes as they exhibit primary defects in both glucose and lipid metabolism (Corpeleijn et al. 2010; Gaster et al. 2004; Kase et al. 2015). It has also been shown that myotubes established from athletic subjects have enhanced glucose and lipid metabolism compared with myotubes from sedentary subjects (Lund et al. 2018a, b). Moreover, the ability to switch between glucose and fatty acid oxidation (metabolic switching) is preserved in human myotubes, which supports the hypothesis that metabolic switching is an intrinsic property of skeletal muscle (Ukropcova et al. 2005). In addition to the genetic background, epigenetic mechanisms are probably involved in retaining the in vivo characteristics of the donors in the cultured cells (Aas et al. 2013; Lund et al. 2017).

Obesity, along with insulin resistance and type 2 diabetes mellitus, is linked to reduced lipid oxidation during fasting and impaired postprandial switch from lipid to glucose 
oxidation (Kelley et al. 1999). Furthermore, it has been observed that skeletal muscle cells from obese subjects have reduced capacity to oxidize fatty acids compared with myotubes from lean subjects, which is associated with lipid accumulation and insulin resistance (Holloway et al. 2009).

It is known that there are differences with regard to energy metabolism between genders in vivo (Wang et al. 2011). Women seem to predominantly oxidize carbohydrates in the postprandial state (Levadoux et al. 2001; Uranga et al. 2005), whereas for energy expenditure under higher energy demand, e.g., during exercise, fatty acid oxidation is the predominant source (Tarnopolsky 2008). Furthermore, skeletal muscles of women seem to be better prepared for storage and oxidation of lipids than male skeletal muscles, which in turn facilitate a higher turnover of intramyocellular triacylglycerols (Lundsgaard and Kiens 2014).

Another factor that affects several metabolic processes in skeletal muscle in vivo is age. With increasing age, it has been observed a decrease in insulin sensitivity (Johannsen et al. 2012; Lanza and Nair 2008; Ryan 2000), increased content of intramyocellular triacylglycerol (Crane et al. 2009), increased proportion of fast muscle fibers (D'Antona et al. 2003), reduced skeletal muscle mass (Lexell et al. 1988), reduced content of skeletal muscle peroxisome proliferatoractivated receptor delta (Nilsson et al. 2007), reduced mitochondrial content (Crane et al. 2009; Rooyackers et al. 1996), and function (Johannsen et al. 2012). Increased age has also been associated with a decline in mitochondrial DNA, mRNA abundance, and mitochondrial ATP production (Hebert et al. 2010; Short et al. 2005; Welle et al. 2003). However, it has been suggested that a combination of obesity and inactivity, and not age per se, is most important in the age-related decline in insulin sensitivity (Lanza and Nair 2008).

An important aspect in evaluating research of myotubes obtained from satellite cells is the heterogeneity of muscle fibers and muscles of origin. Mammalian skeletal muscle fibers can be classified based on contractile rates, metabolism, and expression of isoforms of muscle-specific contractile proteins (Schiaffino and Reggiani 2011). Although other specialized functional fiber types exist, most human muscles consist of mixtures of three fiber types (Schiaffino and Reggiani 2011). It has been shown that myotubes coexpress myosin heavy chain (MHC) isoforms regardless of the origin of satellite cells (Aas et al. 2013; Bonavaud et al. 2001), demonstrating that myotubes differ from donor muscle with respect to MHC expression. We have observed that differentiated myotubes contain both slow and fast fiber types (Aas et al. 2013; Lund et al. 2018b). However, the plasticity potential of skeletal muscle cells has also been well described (Schiaffino and Reggiani 2011). To our knowledge, it has not previously been studied whether the muscle of origin affects energy metabolism in myotube cultures.
The aim of the present work was to study if energy metabolism in skeletal muscle cells in vitro was related to muscle of origin, gender, age, or body mass index (BMI) of the cell donors. Myotubes were established from three different skeletal muscles, i.e., musculus ( $m$.) vastus lateralis, $m$. obliquus internus abdominis, and musculi (mm.) interspinales of healthy donors, and energy metabolism in myotubes was examined. We have combined functional metabolic data from five different cohorts, thereby including data from 82 healthy donors.

\section{Methods}

\section{Materials}

Corning ${ }^{\circledR}$ CellBIND ${ }^{\circledR}$ tissue culture plates were from Corning (Schiphol-Rijk, the Netherlands). Nunc ${ }^{\mathrm{TM}}$ Cell Culture Treated Flasks with Filter Caps, Nunc ${ }^{\mathrm{TM}}$ 96-MicroWell ${ }^{\mathrm{TM}}$ plates, DMEM-Glutamax $^{\mathrm{TM}}$ low glucose with sodium pyruvate, DPBS (without $\mathrm{Mg}^{2+}$ and $\mathrm{Ca}^{2+}$ ), FBS, Trypsin-EDTA, penicillin-streptomycin $(10,000 \mathrm{IE} / \mathrm{ml})$, amphotericin $\mathrm{B}$, High-Capacity cDNA Reverse Transcription Kit, TaqMan reverse transcription kit reagents, MicroAmp ${ }^{\circledR}$ Optical 96-well Reaction Plate, MicroAmp ${ }^{\circledR}$ Optical Adhesive Film, Power SYBR $^{\circledR}$ Green PCR Master Mix, and primers for TaqMan PCR were from Thermo Fisher Scientific (Waltham, MA, USA). Ultroser G was from Pall (Cergy-Saint-Christophe, France) and insulin (Actrapid ${ }^{\circledR}$ Penfill $^{\circledR} 100 \mathrm{IE} / \mathrm{ml}$ ) from Novo Nordisk (Bagsvaerd, Denmark). SkBM-kit (SkGM) and BioWhittaker ${ }^{\circledR}$ PBS were from Lonza (Walkersville, MD, USA). Trypan blue $0.4 \%$ solution, DMSO, L-glutamine, BSA (essentially fatty acid free), L-carnitine, D-glucose, oleic acid (18:1, n-9), and HEPES were from Sigma-Aldrich (St. Louis, MO, USA). RNeasy Mini Kit was from QIAGEN (Venlo, the Netherlands). D- $\left[{ }^{14} \mathrm{C}(\mathrm{U})\right]$ Glucose $(2.9-5 \mathrm{mCi} /$ mmol) and $\left[1-{ }^{14} \mathrm{C}\right]$ oleic acid $(56.3 \mathrm{mCi} / \mathrm{mmol})$ were from PerkinElmer NEN ${ }^{\circledR}$ (Boston, MA, USA). OptiPhase Supermix, 96-well Isoplate ${ }^{\circledR}$, Unifilter ${ }^{\circledR}-96 \mathrm{GF} / \mathrm{B}$, and TopSeal ${ }^{\circledR}$-A transparent film were from PerkinElmer (Shelton, CT, USA). Bio-Rad Protein Assay Dye Reagent Concentrate was from Bio-Rad (Copenhagen, Denmark).

\section{Culturing of human myotubes}

Multinucleated human myotubes were established by activation and proliferation of satellite cells isolated from a small muscle biopsy (100-200 mg) of m. obliquus internus abdominis, $m$. vastus lateralis, or $m m$. interspinales. For the proliferation of myoblasts, DMEM-Glutamax ${ }^{\mathrm{TM}}(5.5 \mathrm{mM}$ glucose) medium supplemented with FBS ( $2 \%)$, Ultroser G (2\%), HEPES, penicillin/streptomycin, gentamicin, and amphotericin B was used. At approximately $80 \%$ confluence, the culture medium was changed to DMEM-Glutamax ${ }^{\mathrm{TM}}$ 
(5.5 mM glucose) supplemented with FBS (2\%), insulin (25 pM), penicillin/streptomycin, gentamicin, and amphotericin B to initiate differentiation into multinucleated myotubes. The cells were allowed to differentiate for 7 days. During the culturing process, muscle cells were incubated in a humidified $\mathrm{CO}_{2}(5 \%)$ atmosphere at $37{ }^{\circ} \mathrm{C}$, and the medium was changed every 2 to 3 days.

\section{Substrate oxidation assay}

Skeletal muscle cells (7000 cells/well) were cultured in 96-well CellBIND ${ }^{\circledR}$ microplates. D- $\left[{ }^{14} \mathrm{C}(\mathrm{U})\right]$ Glucose $(0.5 \mu \mathrm{Ci} / \mathrm{ml}$, $100 \mu \mathrm{M}$, or $200 \mu \mathrm{M})$ or $\left[1-{ }^{14} \mathrm{C}\right]$ oleic acid $(0.5 \mu \mathrm{Ci} / \mathrm{ml}$, $100 \mu \mathrm{M}$ ) was given during 4-h trapping as described previously (Wensaas et al. 2007). In brief, a 96-well UniFilter ${ }^{\circledR}$ microplate (PerkinElmer, Shelton, CT, USA), activated for the capture of $\mathrm{CO}_{2}$ by the addition of $1 \mathrm{M} \mathrm{NaOH}$, was mounted on top of the 96-well plate. After incubation, the cells were washed and harvested in $0.1 \mathrm{M} \mathrm{NaOH}$. The ${ }^{14} \mathrm{CO}_{2}$ trapped in the filter and cellassociated (CA) glucose was measured with a 2450 MicroBeta $^{2}$ scintillation counter (PerkinElmer). The sum of ${ }^{14} \mathrm{CO}_{2}$ and remaining $\mathrm{CA}$ radioactivity was considered an estimation of total cellular uptake of substrate: $\mathrm{CO}_{2}+\mathrm{CA}$. All data were related to total cell protein concentration measured in the cell lysates by the Bio-Rad protein assay.

\section{RNA isolation and analysis of gene expression by real- time qPCR}

Skeletal muscle cells were cultured and differentiated before total RNA was isolated using the RNeasy Mini Kit according to the supplier's protocol. RNA was reversely transcribed with a High-Capacity cDNA Reverse Transcription Kit and TaqMan Reverse Transcription Reagents using a PerkinElmer Thermal Cycler 9600. Primers were designed using Primer Express ${ }^{\circledR}$ and qPCR was performed using an ABI PRISM 7000 Detection system (Thermo Fisher Scientific). Expression levels were normalized to the housekeeping gene acidic ribosomal phosphoprotein $\mathrm{P} 0$ ( $R P L P O)$. Glyceraldehyde-3-phosphate dehydrogenase $(G A P D H)$ was also analyzed as a housekeeping gene; there were no differences between normalizing for RPLPO or GAPDH. The following forward and reverse primers were used at a concentration of $30 \mu \mathrm{M}$ : GAPDH (acc. no.: NM002046), pyruvate dehydrogenase kinase 4 (PDK4, acc. no.: BC040239), peroxisome proliferator-activated receptor gamma coactivator 1 alpha (PPARGC1A, acc. no.: NM013261.3), and RPLP0 (acc. no.: M17885).

\section{Presentation of data and statistics}

All individual data are presented in Figs. 1, 2, 3, and 4. The value $n$ represents the number of different donors, each with at least duplicate observations. Statistical analyses were performed using GraphPad Prism 8 for Windows (GraphPad Software, Inc., La Jolla, CA, USA) or SPSS version 25 $\left(\right.$ IBM $^{\circledR}$ SPSS $^{\circledR}$ Statistics for Windows, Armonk, NY, USA). Two-way ANOVA with Tukey's correction was used to evaluate differences between donors of different muscles (Table 1), whereas unpaired Student's $t$ test was used to evaluate differences between genders within a single muscle (Table 1). Multiple regression analyses were performed where age, BMI, gender, and muscle of origin ( $m$. obliquus internus abdominis and $\mathrm{mm}$. interspinales relative to $m$. vastus lateralis) were used as independent variables to determine substrate uptake and oxidation, whereas linear regression analyses were used to study the relationship between oleic acid oxidation and gene expressions of $P D K 4$ and $P P A R G C 1 A$ in myotubes. A $p$ value $\leq 0.050$ was considered significant.

\section{Results}

In the current work, we have explored whether certain donor characteristics can affect metabolic findings in human myotubes. Energy metabolism in cultured cells was related to donor characteristics from five different myotube cohorts, established from satellite cells isolated from biopsies from three different skeletal muscles, from healthy male and female donors, with varying age and BMI (Table 1). By doing this, we have included data from up to 82 donors in total. There were no statistically significant differences in age or BMI between male and female donors among the different muscles, nor across different muscles. However, no biopsies were taken from musculus vastus lateralis of female donors, which is a weakness of the present study (Table 1).

\section{Cellular energy metabolism parameters presented by gender, donor age, body mass index, and muscle of origin}

Our data set consists of 80 individual results from substrate oxidation experiments with radiolabeled glucose, and 82 individual results from substrate oxidation experiments with radiolabeled oleic acid. Individual data on glucose uptake, glucose oxidation, oleic acid uptake, and oleic acid oxidation in cultured myotubes are presented by gender (Fig. 1), donor age (Fig. 2), BMI (Fig. 3), and muscle of origin (Fig. 4).

\section{Multiple linear regression analyses}

To explore the impact of donor age, gender, BMI, and muscle of origin on the metabolic parameters, and to avoid confounding factors when comparing variables of the cohorts, multiple regression analyses were performed for the statistical 
Table 1 Donor characteristics

\begin{tabular}{|c|c|c|c|c|c|c|}
\hline \multirow[b]{2}{*}{ Gender } & \multicolumn{2}{|c|}{$\begin{array}{l}\text { Musculus obliquus internus } \\
\text { abdominis }\end{array}$} & \multicolumn{2}{|c|}{ Musculus vastus lateralis } & \multicolumn{2}{|c|}{ Musculi interspinales } \\
\hline & $\begin{array}{l}\text { Female } \\
(n=23)\end{array}$ & $\begin{array}{l}\text { Male } \\
(n=9)\end{array}$ & $\begin{array}{l}\text { Female } \\
(n=0)\end{array}$ & $\begin{array}{l}\text { Male } \\
(n=35)\end{array}$ & $\begin{array}{l}\text { Female } \\
(n=9)\end{array}$ & $\begin{array}{l}\text { Male } \\
(n=6)\end{array}$ \\
\hline Age (years) & $47.9 \pm 2.2$ & $41.2 \pm 3.6$ & NA & $38.0 \pm 2.3$ & $47.9 \pm 2.2$ & $43.2 \pm 5.1$ \\
\hline $\begin{array}{l}\text { BMI } \\
\left(\mathrm{kg} / \mathrm{m}^{2}\right)\end{array}$ & $29.6 \pm 2.5$ & $31.1 \pm 4.1$ & NA & $25.9 \pm 0.7$ & $25.7 \pm 1.8$ & $29.4 \pm 1.7$ \\
\hline
\end{tabular}

Values are given as mean \pm SEM. $B M I$, body mass index; $N A$, not available

analyses. All independent variables (donor age, gender, BMI, and muscle of origin) were included in the model, and uptake and oxidation of glucose and oleic acid were used as dependent variables. To compare muscle of origin, $m$. vastus lateralis was used as reference muscle.

When controlling for BMI, gender, age, and muscle of origin, none of these in vivo variables had a significant effect on cellular glucose uptake, and only donor age had a significant impact on cellular glucose oxidation (Table 2).

The multiple regression analysis also showed that BMI was a statistically significant variable that affected oleic acid uptake and that donor age was the sole significant variable to impact cellular oleic acid oxidation (Table 3).
Taken together, with advancing donor age, both glucose and oleic acid oxidation were reduced in cultured myotubes, whereas an increase in donor BMI resulted in increased cellular uptake of oleic acid. Glucose uptake was not significantly affected by gender, age, or BMI of the donors and did not differ between cells from different skeletal muscles.

\section{Correlations between gene expression of PDK4 and PPARGC1A and donor age}

PDK 4 and PGC1 $\alpha$ are two drivers of substrate oxidation, and given the impact age had on substrate oxidation in cultured human myotubes, we performed linear regression
Fig. 1 Cellular energy metabolism presented by gender. a Glucose uptake, $\mathbf{b}$ glucose oxidation, c oleic acid uptake, and d oleic acid oxidation in cultured myotubes established from male and female volunteers. Results are presented individually and with mean \pm SEM from experiments on myotubes from a, b 80 (49 males and 31 females) participants or c, $\mathbf{d} 82$ (50 males and 32 females) participants

\section{a}

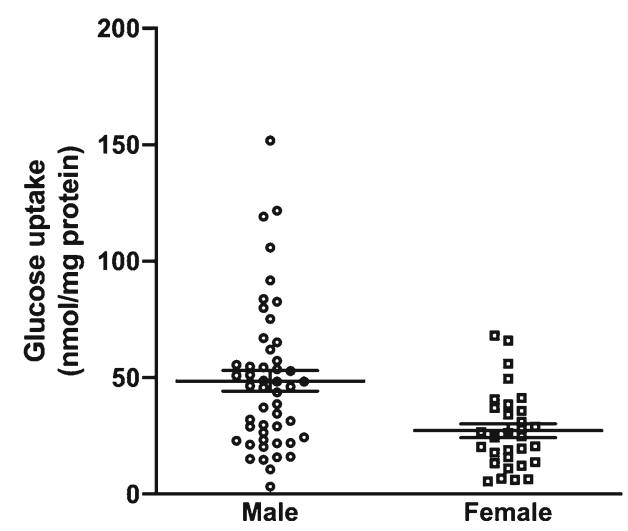

C

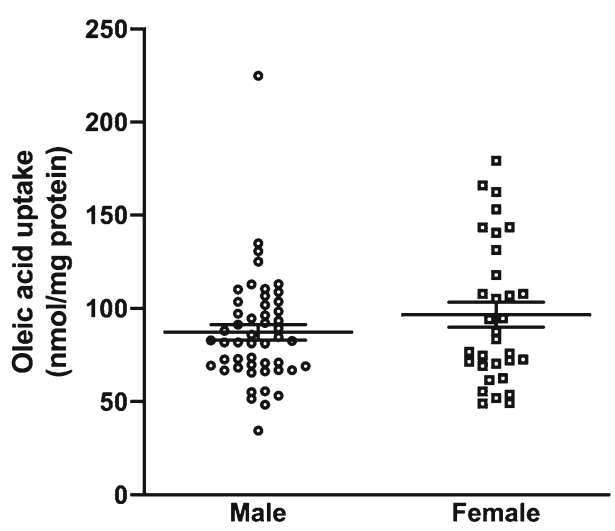

b

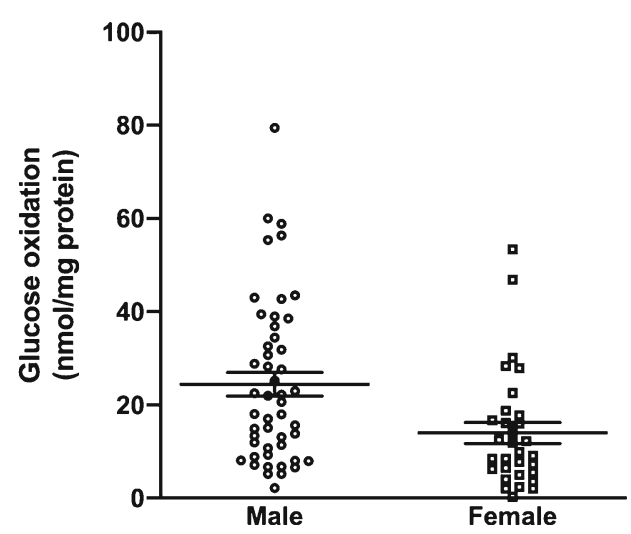

d

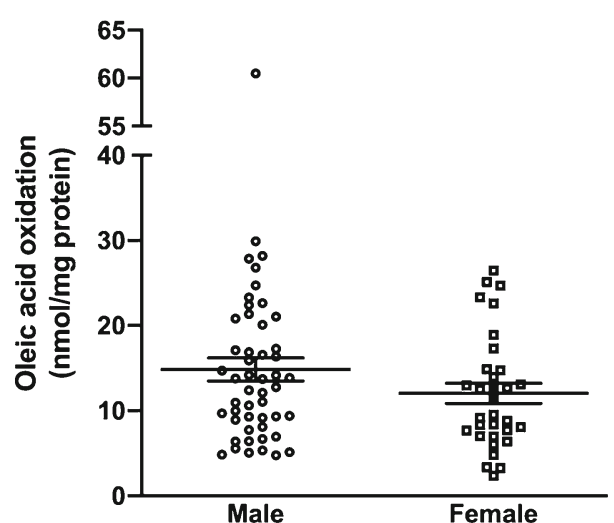


Fig. 2 Cellular energy metabolism presented by donor age. a Glucose uptake, b glucose oxidation, c oleic acid uptake, and d oleic acid oxidation in cultured human myotubes. Results are presented individually from experiments on myotubes from a b 80 or $\mathbf{c}, \mathbf{d} 82$ participants
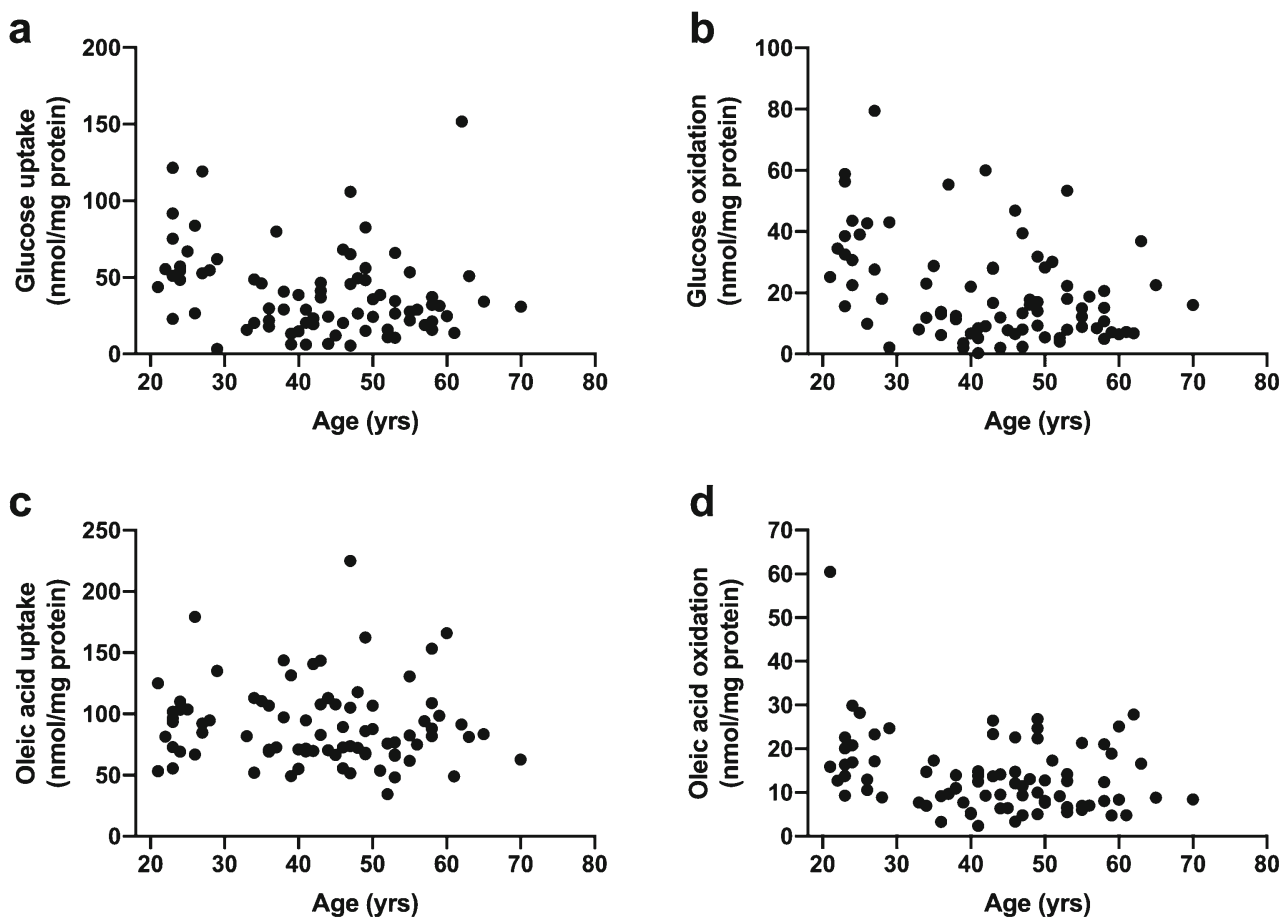

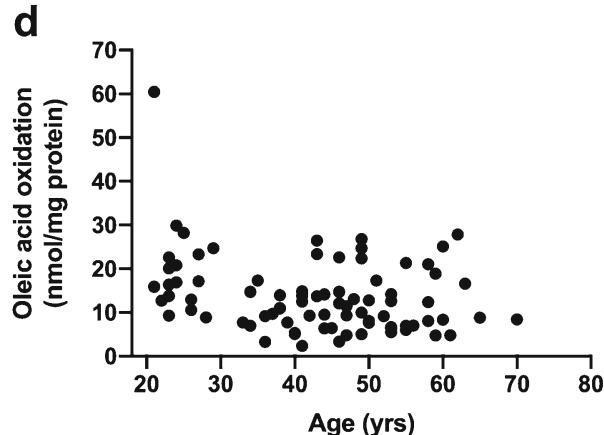

analyses between donor age and mRNA expression of PDK4 and PPARGC1A in myotubes from a subset of the donors (45 and 46 donors, Fig. 5 a and b, respectively). The mRNA expression in the myotubes of these genes did not correlate with the age of the donors (Fig. 5).

\section{Discussion}

In the present study, we have examined which in vivo variables that influence cellular uptake and oxidation of glucose and oleic acid in vitro in myotubes based on metabolic data
Fig. 3 Cellular energy metabolism presented by body mass index (BMI) of the donors. a Glucose uptake, b glucose oxidation, $\mathbf{c}$ oleic acid uptake, and $\mathbf{d}$ oleic acid oxidation in cultured human myotubes. Results are presented individually from experiments on myotubes from $\mathbf{a}, \mathbf{b}$ 80 or $\mathbf{c}, \mathbf{d} 82$ participants
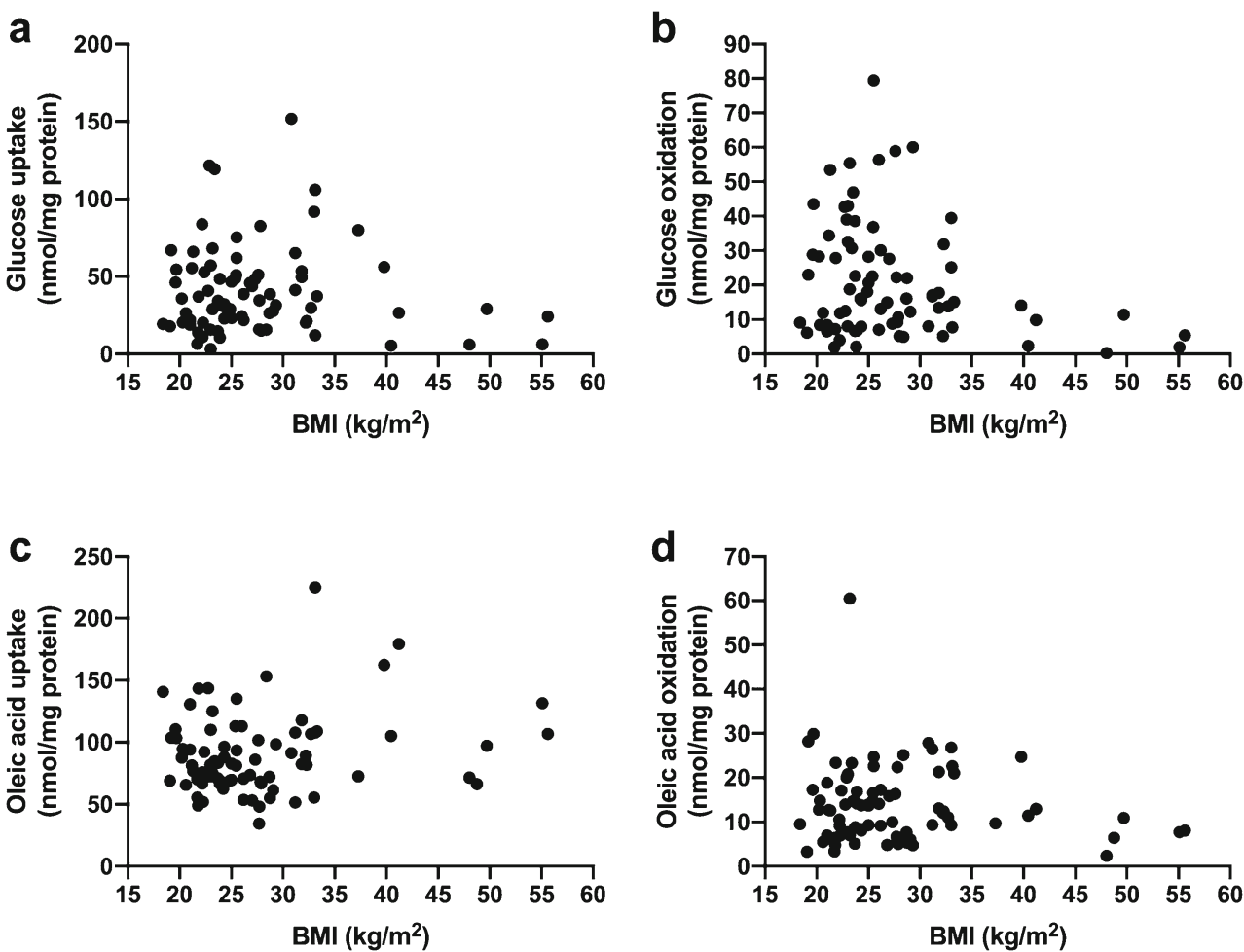
Fig. 4 Cellular energy metabolism presented by the muscle of origin. a Glucose uptake, b glucose oxidation, c oleic acid uptake, and $\mathbf{d}$ oleic acid oxidation in cultured myotubes established from three different muscles. Results are presented individually and with mean \pm SEM from 80 to 82 individual experiments: a, b 30 or $\mathbf{c}, \mathbf{d} 32$ experiments on myotubes from $m$. obliquus internus abdominis, 35 experiments on myotubes from $m$. vastus lateralis, and 15 experiments on myotubes from mm. interspinales a

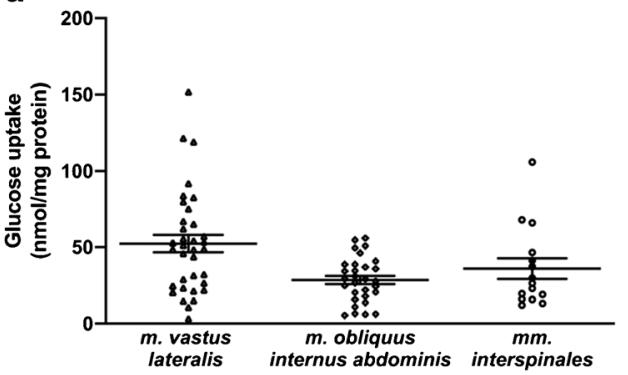

C

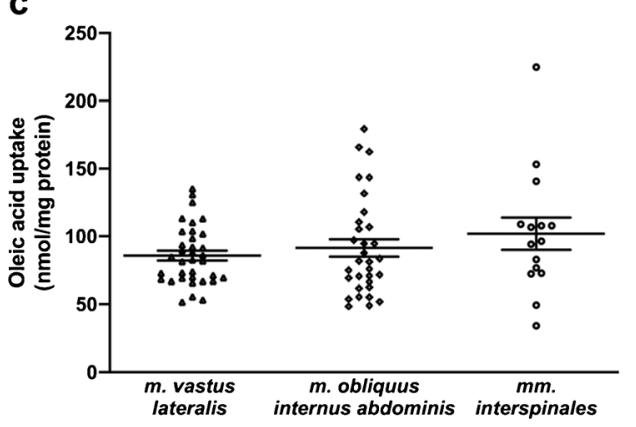

b

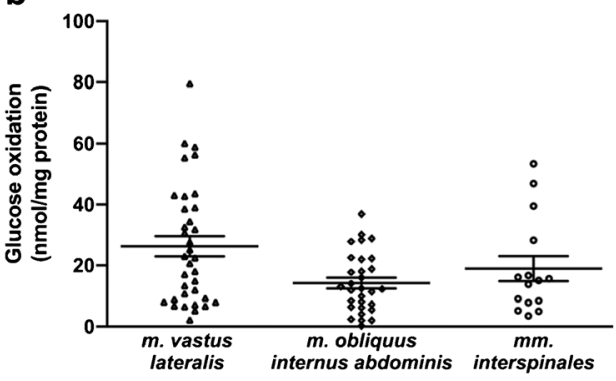

d

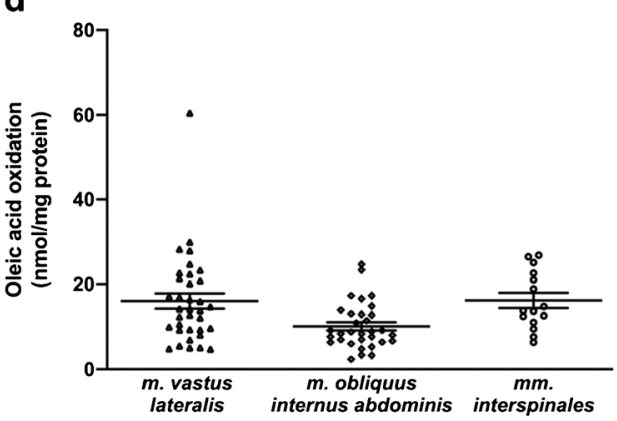

from five different cohorts, including up to 82 donors. To our knowledge, no previous studies have included a sample size as large as the present study, with all cell experiments performed under the same experimental conditions. Only donor age was a statistically significant predictor for cellular substrate oxidation, whereas cellular uptake of oleic acid was dependent on the BMI of the donors. There were no statistically significant in vivo predictors for cellular glucose uptake.

Aging has been associated with reduced skeletal muscle function (Power et al. 2013) and mitochondrial dysfunction (Short et al. 2005). During the aging process, it has been observed increased mutations in mitochondrial DNA, decreased activity of certain mitochondrial enzymes, and reduced mitochondrial content with increased morphological changes (Peterson et al. 2012). Part of the decline in mitochondrial function appears to be due to alterations in mitochondrial synthesis and degradation, whereas the remainder is attributed to reduced physical activity (Carter et al. 2015). Given the central role of mitochondria in energy homeostasis, it was expected that myotube energy metabolism also would be affected by aging. In a study comparing myotubes from young and middle-aged men, it was shown a tendency towards lower glucose uptake in myotubes from aged men (Bunprajun et al. 2013). We observed a negative association between cellular glucose uptake and oxidation as well as oleic acid oxidation with donor age after correcting for gender, BMI, and muscle of origin.

Given the impact donor age had on substrate oxidation in the myotubes, we examined in a subset of the donors whether cellular mRNA expression of two important drivers of substrate
Table 2 Multiple linear regression analysis between selected variables in vivo and glucose metabolism in cultured human myotubes

\begin{tabular}{llrl}
\hline In vitro variable & In vivo variable & Beta & $p$ value \\
\hline Glucose uptake (model $\left.R^{2}=.177\right)$ & BMI & 0.002 & 0.989 \\
& Gender & 0.124 & 0.432 \\
& mm. interspinales & -0.114 & 0.408 \\
& Age & -0.119 & 0.305 \\
Glucose oxidation (model $\left.R^{2}=0.207\right)$ & m. obliquus internus abdominis & -0.289 & 0.087 \\
& mm. interspinales & -0.030 & 0.825 \\
& Gender & 0.081 & 0.601 \\
& m. obliquus internus abdominis & -0.167 & 0.310 \\
& BMI & -0.159 & 0.147 \\
& Age & -0.275 & $0.017 *$ \\
\hline
\end{tabular}

*Statistically significant ( $p \leq 0.050$, multiple regression analysis) from 80 individual experiments $(n=80) . B M I$, body mass index; m., musculus; mm., musculi 
Table 3 Multiple linear regression analysis between selected variables in vivo and oleic acid metabolism in cultured human myotubes

\begin{tabular}{llrl}
\hline In vitro variable & In vivo variable & Beta & $p$ value \\
\hline Oleic acid uptake (model $\left.R^{2}=.134\right)$ & m. obliquus internus abdominis & -0.090 & 0.595 \\
& mm. interspinales & 0.178 & 0.201 \\
& Gender & -0.194 & 0.219 \\
& Age & -0.205 & 0.082 \\
Oleic acid oxidation (model $\left.R^{2}=0.174\right)$ & BMI & 0.224 & $0.050^{*}$ \\
& BMI & -0.037 & 0.735 \\
& mm. interspinales & 0.047 & 0.729 \\
& Gender & -0.093 & 0.544 \\
& m. obliquus internus abdominis & -0.300 & 0.072 \\
& Age & -0.264 & $0.023^{*}$ \\
\hline
\end{tabular}

*Statistically significant ( $p \leq 0.050$, multiple regression analysis) from 82 individual experiments $(n=82) . B M I$, body mass index; m., musculus; mm., musculi oxidation, PDK4 and PPARGC1A, correlated with donor age. PDK4 phosphorylates pyruvate dehydrogenase alpha 1 (PDHA1) at Ser300 and inhibits PDHA1 enzymatic activity, one of the enzymes necessary for driving glucose oxidation via mobilization of pyruvate for the tricarboxylic acid cycle. In our study, cellular mRNA expression of neither PPARGC1A nor $P D K 4$ correlated with donor age. In accordance with our results, in skeletal muscle biopsies, Consitt et al. did not observe different protein expression of PDK4 between younger and older subjects (Consitt et al. 2016) and Short et al. reported that mRNA expression of PPARGC1A in human skeletal muscle biopsies was unaffected by age (Short et al. 2003). However, several studies have reported that mRNA or protein expression of $\mathrm{PGC} 1 \alpha$ is reduced in both slow- and fast-twitch skeletal muscle with increasing age (Chabi et al. 2008; Conley et al. 2007; Ghosh et al. 2011; Koltai et al. 2012; Short et al. 2005), suggesting that reductions in mitochondrial function or content may be put in association with loss of this important coactivator (Carter et al. 2015). Possible

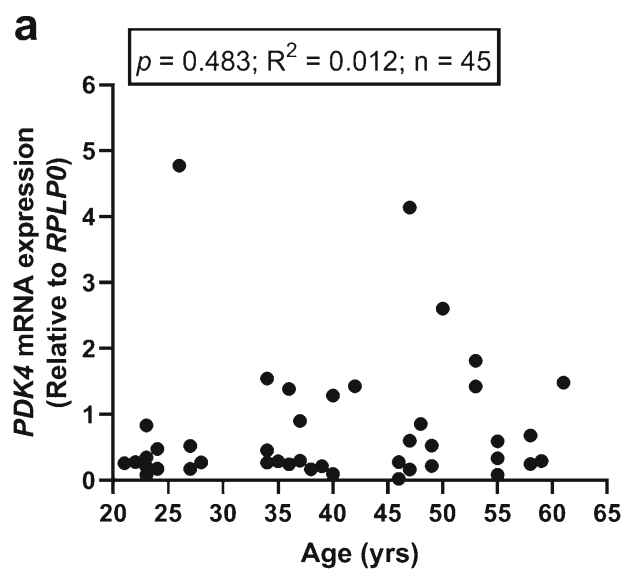

Fig. 5 Impact of donor age on cellular mRNA expression of PDK4 and PPARGC1A. Linear regression analysis between donor age and a cellular mRNA expression of pyruvate dehydrogenase kinase $4(P D K 4)$ relative to housekeeping gene ribosomal protein lateral stalk subunit P0 (RPLPO) reasons for the different findings might be species differences, material examined, number of individual samples included, or whether it is mRNA or protein level that has been examined. Most of the former human studies have examined muscle biopsies (Ghosh et al. 2011), whereas we have used cultured myotubes. Furthermore, animal studies are a source of several of the other available data (Chabi et al. 2008; Koltai et al. 2012). Metabolism between murine animals and humans is different in many ways, particularly are mice and rats much more metabolically active than humans (Kleinert et al. 2018). Moreover, muscle cells in the present study were grown in the presence of glucose as the main energy source. If the myotubes had been treated with for instance fatty acids prior to examination of mRNA expressions, we might have been able to induce differences as these genes mainly are associated with lipid metabolism.

Most subjects with type 2 diabetes are overweight or obese (Smyth and Heron 2006). A high BMI is strongly associated with insulin resistance and type 2 diabetes (Alberti et al. 2007;

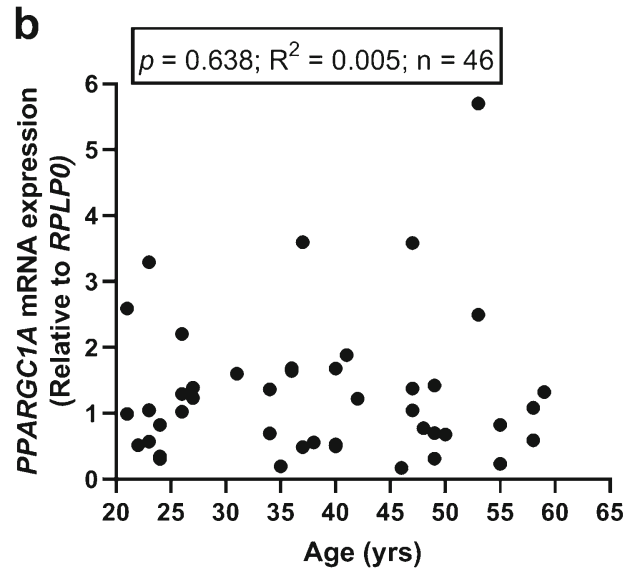

and $\mathbf{b}$ cellular mRNA expression of peroxisome proliferator-activated receptor gamma coactivator 1 alpha (PPARGC1A) relative to housekeeping gene ribosomal protein lateral stalk subunit $\mathrm{P} 0(R P L P 0)$ 
James 2004), and weight loss is thus an important lifestyle change for prevention and treatment of these conditions (Tuomilehto et al. 2001). An enhanced glucose metabolism but unchanged fatty acid metabolism has been reported in cultured human skeletal muscle cells after Roux-en-Y gastric bypass surgery (Nascimento et al. 2015). Others have reported that cultured myotubes established from obese subjects have reduced capacity to oxidize fatty acids compared with cells obtained from lean subjects (Berggren et al. 2008; Boyle et al. 2012; Gaster 2009; Gaster et al. 2004). However, in our study, multiple linear regression analysis revealed that only oleic acid uptake, not oleic acid oxidation or glucose metabolism in myotubes, was affected by donor BMI. We have also recently observed that uptake of palmitic acid was higher in cultured human myotubes from obese compared with myotubes from lean subjects, whereas oxidation of palmitic acid was unaffected (Løvsletten et al. 2020). Furthermore, Bonen et al. described an approximately 4-fold higher transport rate of long-chain fatty acids and triacylglycerol content in giant sarcolemmal vesicles prepared from skeletal muscle biopsies from obese subjects (Bonen et al. 2004).

There have not, as far as we know, been performed any studies to compare energy metabolism in myotubes derived from satellite cells isolated from different human skeletal muscles. Our data set is based on myotubes derived from satellite cells from the three different skeletal muscles, i.e. $m$. vastus lateralis, $\mathrm{m}$. obliquus internus abdominis, and $\mathrm{mm}$. interspinales. Of the three muscles, the latter has, as far as we are aware of, not previously been used for skeletal muscle cellular metabolic studies. Murine and primate studies have shown that $\mathrm{mm}$. interspinales contain a high amount of the slow, oxidative type I fibers, where the amount increased down the vertebras of the spine as the muscle size increased (Neufuss et al. 2014; Schilling 2009). In Fig. 4, there appeared to be slight differences between muscle types, but these were due to confounding factors, such as age.

Differences in skeletal muscle substrate metabolism between genders are well described in vivo (reviewed in Lundsgaard and Kiens (2014)). However, in cultured human myotubes, the gender difference does not seem to be maintained when examined under basal conditions (Rune et al. 2009; Salehzadeh et al. 2011). Studies have shown that the metabolism of glucose and palmitic acid was similar in myotubes from male and female donors (Rune et al. 2009). Despite mRNA expression of several genes important for the metabolism of glucose and fatty acids has been reported to be higher in skeletal muscle biopsies from women than men, the expression was similar in cultured myotubes from the same donors (Rune et al. 2009; Salehzadeh et al. 2011). In the current study, we did not find gender to be a significant determinant of myotube energy metabolism. However, a weakness with the present study is that we did not have cells from biopsies from musculus vastus lateralis of female donors.
To conclude, donor age had a significant impact on both glucose and oleic acid oxidation in cultured human myotubes, whereas BMI of the donors influenced only oleic acid uptake by the cells. Therefore, in studies aiming to study metabolic processes in cultured myotubes, the age of the muscle biopsy donors should be especially emphasized.

Acknowledgments The authors acknowledge all volunteers participating in the studies. We also thank Eili Tranheim Kase for the preliminary scientific discussions. Jenny Lund and Arild C. Rustan are members of the COST Action CA15203 MitoEAGLE.

Funding Open Access funding provided by University of Oslo (incl Oslo University Hospital). This work was funded by research grants from OsloMet - Oslo Metropolitan University, the University of Oslo, the Norwegian Diabetes Association, and Anders Jahre's Foundation.

\section{Compliance with ethical standards}

Conflict of interest The authors declare that they have no conflicts of interest.

Ethical approval All procedures performed in studies involving human participants were in accordance with the ethical standards of the Regional Committee for Medical and Health Research Ethics (REK) South East, Oslo, Norway (reference numbers: S-04133, S-09078d 2009/166, 2011/2207, and 2015/124) and REK North, Tromsø, Norway (reference number: 2011/882). The study adhered to the 1964 Helsinki declaration and its later amendments or comparable ethical standards.

Informed consent The biopsies were obtained after informed written consent and approval by the previously mentioned Regional Committee for Medical and Health Research.

Open Access This article is licensed under a Creative Commons Attribution 4.0 International License, which permits use, sharing, adaptation, distribution and reproduction in any medium or format, as long as you give appropriate credit to the original author(s) and the source, provide a link to the Creative Commons licence, and indicate if changes were made. The images or other third party material in this article are included in the article's Creative Commons licence, unless indicated otherwise in a credit line to the material. If material is not included in the article's Creative Commons licence and your intended use is not permitted by statutory regulation or exceeds the permitted use, you will need to obtain permission directly from the copyright holder. To view a copy of this licence, visit http://creativecommons.org/licenses/by/4.0/.

\section{References}

Aas V, Bakke SS, Feng YZ, Kase ET, Jensen J, Bajpeyi S, Thoresen GH, Rustan AC (2013) Are cultured human myotubes far from home? Cell Tissue Res 354:671-682

Alberti KGMM, Zimmet P, Shaw J (2007) International diabetes federation: a consensus on type 2 diabetes prevention. Diabet Med 24: 451-463

Berggren JR, Boyle KE, Chapman WH, Houmard JA (2008) Skeletal muscle lipid oxidation and obesity: influence of weight loss and exercise. Am J Physiol Endocrinol Metab 294:E726-E732 
Bonavaud S, Agbulut O, Nizard R, D'honneur G, Mouly V, ButlerBrowne G (2001) A discrepancy resolved: human satellite cells are not preprogrammed to fast and slow lineages. Neuromuscul Disord 11:747-752

Bonen A, Parolin ML, Steinberg GR, Calles-Escandon J, Tandon NN, Glatz JF, Luiken JJ, Heigenhauser GJ, Dyck DJ (2004) Triacylglycerol accumulation in human obesity and type 2 diabetes is associated with increased rates of skeletal muscle fatty acid transport and increased sarcolemmal FAT/CD36. FASEB J 18:1144 1146

Boyle KE, Zheng D, Anderson EJ, Neufer PD, Houmard JA (2012) Mitochondrial lipid oxidation is impaired in cultured myotubes from obese humans. Int J Obes 36:1025-1031

Bunprajun T, Henriksen TI, Scheele C, Pedersen BK, Green CJ (2013) Lifelong physical activity prevents aging-associated insulin resistance in human skeletal muscle myotubes via increased glucose transporter expression. PLoS One 8:e66628

Carter HN, Chen CC, Hood DA (2015) Mitochondria, muscle health, and exercise with advancing age. Physiology 30:208-223

Chabi B, Ljubicic V, Menzies KJ, Huang JH, Saleem A, Hood DA (2008) Mitochondrial function and apoptotic susceptibility in aging skeletal muscle. Aging Cell 7:2-12

Conley KE, Marcinek DJ, Villarin J (2007) Mitochondrial dysfunction and age. Curr Opin Clin Nutr Metab Care 10:688-692

Consitt LA, Saxena G, Saneda A, Houmard JA (2016) Age-related impairments in skeletal muscle PDH phosphorylation and plasma lactate are indicative of metabolic inflexibility and the effects of exercise training. Am J Physiol Endocrinol Metab 311:E145-E156

Corpeleijn E, Hessvik NP, Bakke SS, Levin K, Blaak EE, Thoresen GH, Gaster M, Rustan AC (2010) Oxidation of intramyocellular lipids is dependent on mitochondrial function and the availability of extracellular fatty acids. Am J Physiol Endocrinol Metab 299:E14-E22

Crane JD, Devries MC, Safdar A, Hamadeh MJ, Tarnopolsky MA (2009) The effect of aging on human skeletal muscle mitochondrial and intramyocellular lipid ultrastructure. J Gerontol A Biomed Sci Med Sci 65:119-128

D'Antona G, Pellegrino MA, Adami R, Rossi R, Carlizzi CN, Canepari M, Saltin B, Bottinelli R (2003) The effect of ageing and immobilization on structure and function of human skeletal muscle fibres. J Physiol 552:499-511

Gaster M (2009) Reduced lipid oxidation in myotubes established from obese and type 2 diabetic subjects. Biochem Biophys Res Commun 382:766-770

Gaster M, Kristensen S, Beck-Nielsen H, Schrøder H (2001) A cellular model system of differentiated human myotubes. Apmis 109:735744

Gaster M, Rustan AC, Aas V, Beck-Nielsen H (2004) Reduced lipid oxidation in skeletal muscle from type 2 diabetic subjects may be of genetic origin: evidence from cultured myotubes. Diabetes 53: 542-548

Ghosh S, Lertwattanarak R, Lefort N, Molina-Carrion M, Joya-Galeana J, Bowen BP, de Jesus Garduno-Garcia J, Abdul-Ghani M, Richardson A, DeFronzo RA (2011) Reduction in reactive oxygen species production by mitochondria from elderly subjects with normal and impaired glucose tolerance. Diabetes 60:2051-2060

Hebert SL, Lanza IR, Nair KS (2010) Mitochondrial DNA alterations and reduced mitochondrial function in aging. Mech Ageing Dev 131: 451-462

Henry RR, Abrams L, Nikoulina S, Ciaraldi TP (1995) Insulin action and glucose metabolism in nondiabetic control and NIDDM subjects: comparison using human skeletal muscle cell cultures. Diabetes 44:936-946

Holloway GP, Bonen A, Spriet LL (2009) Regulation of skeletal muscle mitochondrial fatty acid metabolism in lean and obese individuals. Am J Clin Nutr 89:455s-462s
James PT (2004) Obesity: the worldwide epidemic. Clin Dermatol 22: 276-280

Johannsen DL, Conley KE, Bajpeyi S, Punyanitya M, Gallagher D, Zhang Z, Covington J, Smith SR, Ravussin E (2012) Ectopic lipid accumulation and reduced glucose tolerance in elderly adults are accompanied by altered skeletal muscle mitochondrial activity. J Clin Endocrinol Metab 97:242-250

Kase ET, Feng YZ, Badin P-M, Bakke SS, Laurens C, Coue M, Langin D, Gaster M, Thoresen GH, Rustan AC (2015) Primary defects in lipolysis and insulin action in skeletal muscle cells from type 2 diabetic individuals. Biochim Biophys Acta 1851:1194-1201

Kelley DE, Goodpaster B, Wing RR, Simoneau J-A (1999) Skeletal muscle fatty acid metabolism in association with insulin resistance, obesity, and weight loss. Am J Physiol Endocrinol Metab 277: E1130-E1141

Kleinert M, Clemmensen C, Hofmann SM, Moore MC, Renner S, Woods SC, Huypens P, Beckers J, De Angelis MH, Schürmann A (2018) Animal models of obesity and diabetes mellitus. Nat Rev Endocrinol 14:140

Koltai E, Hart N, Taylor AW, Goto S, Ngo JK, Davies KJ, Radak Z (2012) Age-associated declines in mitochondrial biogenesis and protein quality control factors are minimized by exercise training. Am J Phys Regul Integr Comp Phys 303:R127-R134

Lanza IR, Nair KS (2008) Muscle mitochondrial changes with aging and exercise. Am J Clin Nutr 89:467S-471S

Levadoux E, Morio B, Montaurier C, Puissant V, Boirie Y, Fellmann N, Picard B, Rousset P, Beaufrere B, Ritz P (2001) Reduced wholebody fat oxidation in women and in the elderly. Int J Obes 25:39

Lexell J, Taylor CC, Sjöström M (1988) What is the cause of the ageing atrophy?: Total number, size and proportion of different fiber types studied in whole vastus lateralis muscle from 15-to 83-year-old men. J Neurol Sci 84:275-294

Løvsletten NG, Rustan AC, Laurens C, Thoresen GH, Moro C, Nikolić N (2020) Primary defects in lipid handling and resistance to exercise in myotubes from obese donors with and without type 2 diabetes. Appl Physiol Nutr Metab 45:169-179

Lund J, Rustan AC, Løvsletten NG, Mudry JM, Langleite TM, Feng YZ, Stensrud C, Brubak MG, Drevon CA, Birkeland KI (2017) Exercise in vivo marks human myotubes in vitro: training-induced increase in lipid metabolism. PLoS One 12:e0175441

Lund J, Helle SA, Li Y, Løvsletten NG, Stadheim HK, Jensen J, Kase ET, Thoresen GH, Rustan AC (2018a) Higher lipid turnover and oxidation in cultured human myotubes from athletic versus sedentary young male subjects. Sci Rep:8

Lund J, Tangen DS, Wiig H, Stadheim HK, Helle SA, Birk BJ, Ingemann-Hansen T, Rustan AC, Thoresen GH, Wojtaszewski JF (2018b) Glucose metabolism and metabolic flexibility in cultured skeletal muscle cells is related to exercise status in young male subjects. Arch Physiol Biochem 124:119-130

Lundsgaard A-M, Kiens B (2014) Gender differences in skeletal muscle substrate metabolism-molecular mechanisms and insulin sensitivity. Front Endocrinol 5:195

Nascimento EB, Riedl I, Jiang LQ, Kulkarni SS, Näslund E, Krook A (2015) Enhanced glucose metabolism in cultured human skeletal muscle after Roux-en-Y gastric bypass surgery. Surg Obes Relat Dis 11:592-601

Neufuss J, Hesse B, Thorpe SK, Vereecke EE, D'Aout K, Fischer MS, Schilling N (2014) Fibre type composition in the lumbar perivertebral muscles of primates: implications for the evolution of orthogrady in hominoids. J Anat 224:113-131

Nilsson E, Poulsen P, Sjögren M, Ling C, Ridderstråle M, Groop L, Vaag A (2007) Regulation of skeletal muscle PPAR $\delta$ mRNA expression in twins. J Physiol 584:1011-1017

Peterson CM, Johannsen DL, Ravussin E (2012) Skeletal muscle mitochondria and aging: a review. J Aging Res 2012 
Power GA, Dalton BH, Rice CL (2013) Human neuromuscular structure and function in old age: a brief review. J Sport Health Sci 2:215-226

Rooyackers OE, Adey DB, Ades PA, Nair KS (1996) Effect of age on in vivo rates of mitochondrial protein synthesis in human skeletal muscle. Proc Natl Acad Sci 93:15364-15369

Rune A, Salehzadeh F, Szekeres F, Kühn I, Osler M, Al-Khalili L (2009) Evidence against a sexual dimorphism in glucose and fatty acid metabolism in skeletal muscle cultures from age-matched men and post-menopausal women. Acta Physiol 197:207-215

Ryan AS (2000) Insulin resistance with aging. Sports Med 30:327-346

Salehzadeh F, Rune A, Osler M, Al-Khalili L (2011) Testosterone or 17estradiol exposure reveals sex-specific effects on glucose and lipid metabolism in human myotubes. J Endocrinol 210:219-229

Schiaffino S, Reggiani C (2011) Fiber types in mammalian skeletal muscles. Physiol Rev 91:1447-1531

Schilling N (2009) Metabolic profile of the perivertebral muscles in small therian mammals: implications for the evolution of the mammalian trunk musculature. Zoology (Jena) 112:279-304

Short KR, Vittone JL, Bigelow ML, Proctor DN, Rizza RA, CoenenSchimke JM, Nair KS (2003) Impact of aerobic exercise training on age-related changes in insulin sensitivity and muscle oxidative capacity. Diabetes 52:1888-1896

Short KR, Bigelow ML, Kahl J, Singh R, Coenen-Schimke J, Raghavakaimal S, Nair KS (2005) Decline in skeletal muscle mitochondrial function with aging in humans. Proc Natl Acad Sci 102: $5618-5623$

Smyth S, Heron A (2006) Diabetes and obesity: the twin epidemics. Nat Med 12:75

Tarnopolsky MA (2008) Sex differences in exercise metabolism and the role of 17-beta estradiol. Med Sci Sports Exerc 40:648-654
Thompson DB, Pratley R, Ossowski V (1996) Human primary myoblast cell cultures from non-diabetic insulin resistant subjects retain defects in insulin action. J Clin Invest 98:2346-2350

Tuomilehto J, Lindström J, Eriksson JG, Valle TT, Hämäläinen H, Ilanne-Parikka P, Keinänen-Kiukaanniemi S, Laakso M, Louheranta A, Rastas M (2001) Prevention of type 2 diabetes mellitus by changes in lifestyle among subjects with impaired glucose tolerance. N Engl J Med 344:1343-1350

Ukropcova B, McNeil M, Sereda O, De Jonge L, Xie H, Bray GA, Smith SR (2005) Dynamic changes in fat oxidation in human primary myocytes mirror metabolic characteristics of the donor. J Clin Invest 115:1934-1941

Uranga AP, Levine J, Jensen M (2005) Isotope tracer measures of meal fatty acid metabolism: reproducibility and effects of the menstrual cycle. Am J Physiol Endocrinol Metab 288:E547-E555

Wang Z, Ying Z, Bosy-Westphal A, Zhang J, Heller M, Later W, Heymsfield SB, Müller MJ (2011) Evaluation of specific metabolic rates of major organs and tissues: comparison between men and women. Am J Hum Biol 23:333-338

Welle S, Bhatt K, Shah B, Needler N, Delehanty JM, Thornton CA (2003) Reduced amount of mitochondrial DNA in aged human muscle. J Appl Physiol 94:1479-1484

Wensaas A, Rustan A, Lövstedt K, Kull B, Wikström S, Drevon C, Hallen S (2007) Cell-based multiwell assays for the detection of substrate accumulation and oxidation. J Lipid Res 48:961-967

Publisher's note Springer Nature remains neutral with regard to jurisdictional claims in published maps and institutional affiliations. 